\title{
The Effectiveness of Creative Problem-Solving Learning Model in Mathematics Learning
}

\author{
Riza Yuliana, Dwi Priyo Utomo, Agung Deddiliawan Ismail
}

\author{
Study Program of Mathematics Education \\ Faculty of Teacher Training and Education, \\ University of Muhammadiyah Malang \\ rizayuliana16@gmail.com
}

\begin{abstract}
This research aimed at assessing the effectiveness of the creative problem-solving learning model in $8^{\text {th }}$ grade of mathematics learning. The assessment of the effectiveness of learning model was reviewed based on three aspects, namely students' activities, students' responses to the learning model, and students' learning outcomes. The type and approach, which used in this research, were quantitative descriptive with the research subjects of $8^{\text {th }}$ $\mathrm{C}$ class; moreover, the subjects consisted of 32 students. The instruments used to assess the effectiveness of the learning model were the students' activity observation sheet, students' responses questionnaire, and test sheet. The results of the research showed that the students' activities were categorized as very good, in which the percentages were $84.38 \%$. The students' responses were categorized as very good with a percentage of $82.53 \%$. The students' learning outcomes in a classical manner could be said as complete with the completeness of $71.88 \%$. Therefore, it can be concluded that the implementation of creative problem-solving learning model in mathematics learning can be said as effective.
\end{abstract}

Keywords: Effectiveness, Creative Problem-Solving, Mathematics Learning.

\section{INTRODUCTION}

Mathematics is one of the basic sciences that has an important role in everyday life. Therefore, the implementation of mathematics is always related to daily life. This can be seen from various fields of science that consist of three elements of mathematics.

The importance of mathematics results in every level of education that needs mathematics learning. The purpose of mathematics learning is that the students are able to solve problems in everyday life. This is supported by Firmansyah (2014) who states that mathematics learning aims to prepare the students to be able to face up the changing world that is always developing.

Mathematics learning, which is encountered in education levels, is often associated with problems. These problems can help the students to have the problem-solving ability. Prameswari \& Khabibah (2016) reveal that problems in mathematics are problems that are solved by non-routine procedures so that in solving these problems, the students are required to have the problem-solving ability.

In fact, the mathematical problem-solving abilities of Indonesian students are still relatively low. Shodikin (2015) reveals that the problem-solving ability of Indonesian students has not achieved the minimum level that is considered satisfactory or achieves minimal learning completeness. This is because the learning that carried out by the teacher is less helpful for students to improve their problem-solving ability. Based on interviews with the teachers of Junior High School of Taman Siswa Malang on September $14^{\text {th }}, 2017$, many of these Junior High School Students experienced problems in mathematics learning. The problems, which were difficult for students to be solved, were solving the word problems and are less skilled in completing the number of operations. However, e teachers of Junior High School of Taman Siswa Malang did not know the causes of these problems. Departing from this circumstance, it could be said that the problem-solving abilities possessed by the students of Junior High School 
of Taman Siswa Malang were still lacking. In addition, the results of the interview stated that in learning activities, the teachers rarely used discussion method. This caused the students for being less active in teaching and learning activities. The learning such this way should be changed so that the students could be skilled at solving the problems in mathematics. Retna, Mubarokah, \& Suhartatik (2013) revealed that the students would easily solve mathematics problems if the students were skilled in solving these problems. Thus, a learning that relates to this circumstance is the learning which relates to ability in solving a problem.

Lack of problem-solving ability is influenced by the accuracy of the selection of learning models. The appropriate learning model to improve problem-solving ability is problem-based learning. The benefit of problem-based learning is that the students can have the problemsolving ability (Suprijono, 2012).

The learning model that can improve the students' ability to solve mathematics problems is creative problem-solving learning model. The creative problem-solving learning model is a learning model that concentrates on teaching and problem-solving ability. The benefits of creative problem-solving learning models are that the students will be able to state the sequence of problem-solving steps and the students are able to find the problem-solving strategies (Shoimin, 2014). Thus, this learning model can trigger the students' ability in solving problems.

Syazali (2015) reveals that the creative problem-solving learning model influences the students' mathematical problem-solving ability. Therefore, this learning model can be used to improve the students' mathematical problem-solving ability. Estu (2014) reveals that learning by using creative problem-solving can improve the learning activities and improve the conceptual understanding of mathematics learning. Yudharina (2015) in his research shows that the creative problem-solving learning model can improve the ability to solve the mathematics word problems in the students of State Elementary School of Mejing 2.

Based on the above problems and a review of the previous research, it is expected that the creative problem-solving learning model can be used to trigger the activeness and problemsolving ability in mathematics for the students of Junior High School of Taman Siswa Malang. Therefore, this research aimed at assessing the effectiveness of creative problem-solving learning model on the mathematics learning at 8th grade of Junior High School of Taman Siswa Malang.

\section{RESEARCH METHOD}

The type and approach used in this research were quantitative descriptive. The data were obtained in the form of students' activities data, students' responses, and students' learning outcomes. This research was conducted at Junior High School of Taman Siswa Malang in the second semester of the academic year of 2017/2018. The subjects in research were the students of $8^{\text {th }}$ grade at Junior High School of Taman Siswa Malang, in which it consisted of 28 students.

This research assessed the effectiveness of creative problem-solving learning model in mathematics learning. The learning model was stated to be effective when the students' activities, students' responses were classified into a good category and the students' learning outcomes were stated to be complete. Based on this circumstance, the data collection techniques chosen in this research were adjusted to the type of data that would be obtained and the aspects that would be measured. The data obtained in this research were quantitative data while the measured aspects were the students' activity, the students' response, and the students' learning outcomes. Therefore, the data collection techniques that were in accordance to these things were observation, questionnaire, and test. The observation was used to assess the students' activities during the teaching and learning process, the questionnaires were used to assess the 
students' responses to learning, and test was used to measure the students' learning outcomes. The data obtained would be analyzed by using data analysis techniques. The data that would be analyzed were instrument validation, students' activities, students' responses, and students' learning outcomes.

\section{RESULT AND DISCUSSION}

The results would be presented in this research were in the form of a description of the data analysis obtained from the implementation of learning using creative problem-solving learning model at the $8^{\text {th }}-\mathrm{C}$ class of in Junior High School of Taman Siswa Malang on the material of Polyhedron surface area. The data that would be presented in the results of this research was in the form of students' activities data, students' responses, and students' learning outcomes.

\section{Students' Activities}

The students' activities data were obtained from the observation activity conducted by two observers, namely researcher and teacher during the implementation of the creative problem-solving learning model for $8^{\text {th }}$-C class students Junior High School of Taman Siswa Malang on the material of Polyhedron surface area. The activities were carried out for two meetings, in which the students' activities for each meeting were observed by the observers through the students' activities sheet instrument that previously prepared by the researcher. The analysis results of students' activities would be presented in the following table:

\section{Table 1 The Analysis of Students' Activities}

\begin{tabular}{llcc}
\hline No & \multicolumn{1}{c}{ Indicators } & Overall percentages (\%) & Category \\
\hline 1 & Noticing on to the teacher's explanation & 93,75 & Very Good \\
2 & Understanding the problems given by the & 75 & Good \\
& teacher & & \\
3 & Actively asking and answering questions & 93,75 & Very Good \\
4 & Cooperating in groups & 81,25 & Very Good \\
5 & The ability to express opinions & 75 & Good \\
6 & Giving a chance to argue with friends in a & 81,25 & Very Good \\
& group & & \\
7 & Presenting the results of group discussion & 93,75 & Very Good \\
\hline & $\quad$ Percentage (\%) & 84,38 & Very Good \\
\hline
\end{tabular}

Based on the table 1, it could be seen that the measurement of students' activities was reviewed from 7 indicators which included of noticing to the teacher's explanation, understanding the problems given by the teacher, actively asking and answering questions, cooperating in groups, the ability to express opinions, giving opportunity to friends in groups, presenting the results of group discussion. In the indicator of noticing to the teacher's explanation, the percentage reached $93.75 \%$, in which it was categorized as very good. The indicator of understanding the problems given by the obtained a percentage of $75 \%$. In the actively asking and answering questions indicator, the percentage reached $93.75 \%$ that classified as very good. In the indicator of cooperating in groups, the percentage reached $81.25 \%$, in which it classified as very good category. On the indicator of the ability to express opinions, the percentage of $75 \%$ belonged to the good category. The indicator of giving the opportunity to friends in groups reached a percentage of $81.25 \%$ that classified as a very good category. On the indicator of presenting the results of the group discussion, the percentage reached $93.75 \%$ that classified as the very good category. Based on the percentage values on 
each indicator, the overall percentage was $84.38 \%$. Thus, the overall of students' activities in mathematics learning using creative problem-solving learning model was classified into a very good category.

\section{Students' Responses}

The students' responses data in this research were obtained through the questionnaires given to the students at the third meeting after the implementation of the test activity. The questionnaire data obtained were only 31 data. This happened because one of 32 children was absent during the test activity. The data obtained were analyzed according to the analysis of the data that had been set. The questionnaire data analyzed consisted of 25 items that grouped based on two aspects, namely students' attitudes towards the creative problem-solving learning model with the number of items as many as 13 statements and understanding of the material taught with the number of items as many as 12 statements. The results of data analysis would be presented in the following table:

Table 2 The Analysis of Students' Response Questionnaire

\begin{tabular}{llllll}
\hline No & \multicolumn{1}{c}{ Aspects } & Total & Average & $\begin{array}{l}\text { Percentage } \\
(\%)\end{array}$ & Category \\
\hline 1 & $\begin{array}{l}\text { The students attitudes } \\
\text { towards learning through the } \\
\text { creative problem-solving } \\
\text { learning model }\end{array}$ & 3,27 & 81,29 & Very Good \\
2 & Material understanding & & & \\
\hline \multicolumn{2}{r}{ Overall Percentage (\%) } \\
\hline
\end{tabular}

Based on the table 2, the measured aspects included of the students' attitudes toward mathematics learning through the creative problem-solving learning model and material understanding. In the students' attitudes towards mathematics learning through the creative problem-solving learning model, the number of scores obtained in 1361 with an average of 3.27 and the percentage reaching was $81.29 \%$. Therefore, the percentage was included in the very good category. In the understanding the material, the number of scores obtained reached 1171 with an average of 3.33 and the percentage reached $83.27 \%$. Thus, the percentage was classified into the very good category.

Based on the percentage obtained in both aspects, it could be obtained that the overall percentage reached $82.53 \%$. Thus, the students' responses to mathematics learning through the creative problem-solving learning model could be stated to get very good responses from students.

\section{Students' Learning Outcomes}

The students' learning outcomes data were obtained from the group worksheets $(L K K)$ values of the first and second meetings and the final test conducted at the end of learning. This value was stated to be complete if the students' values individually reached $\geq 75$ and the learning was said to be complete if the percentage of completeness reached $70 \%$. The data analysis of students' learning outcomes would be presented as follows:

Table 3 Mastery Analysis of Student Learning Outcomes

\begin{tabular}{lcccc}
\hline $\begin{array}{l}\text { The number } \\
\text { students' }\end{array}$ & of & $L K K 1$ & LKK 2 & Final Test \\
\cline { 2 - 4 } $\begin{array}{l}\text { completeness } \\
\text { Percentage }\end{array}$ & 28 & 32 & 23 \\
\hline
\end{tabular}


Table 4 Completeness Analysis of Classical Learning Outcomes

\begin{tabular}{ccc}
\hline Criteria & The number of students & Percentage (\%) \\
\hline Complete & 23 & 71,88 \\
Incomplete & 9 & 28,13 \\
\hline
\end{tabular}

Table 3 above showed the data on the learning outcomes that analyzed including the values of $L K K 1, L K K I I$, and the final test. In $L K K 1$, the number of students who completed as many as 28 students with a percentage of $87.5 \%$. In $L K K I I$, the number of students who completed as many as 32 students with a percentage of $100 \%$. In the final test, the number of students who completed as many as 23 students with a percentage of $71.88 \%$.

Table 4 above showed the students' learning completeness classically. Classically, the number of students who could be said to complete was 23 students with a percentage of completeness of $71.88 \%$.

\section{Discussion}

This research was research that measured the effectiveness of the creative problemsolving learning model in mathematics learning at the Junior High School of Taman Siswa Malang. The measurement of the effectiveness of the creative problem-solving learning model in this research was reviewed based on the students' activities, students' responses, and students' learning outcomes on the Polyhedron surface area material. This research was conducted in three meetings where the learning was held for two meetings and the final test and questionnaires were conducted at the third meeting.

The first measurement of the effectiveness of the creative problem-solving learning model in mathematics learning was the students' activities. The assessment of students' activities was carried out through the observations that carried out by two observers. The activity was conducted during two meetings. During the implementation of the creative problem-solving learning model, the students' activities were observed by the observers. The measurement of students' activities based on the aspects and indicators. There were 7 indicators of the students' activities observed. These seven indicators of observation were classified into good to very good categories. The percentage obtained in each indicator reached $75 \%$ to $93.75 \%$. The lowest percentage was obtained from the indicator of understanding the problems given by the teacher, cooperating in groups, and expressing opinions. This happened because there were some students who did not do the observed activity. The highest percentage was obtained from the indicator of actively asking and answering questions and presenting the results of group discussion. The overall percentage of students' activities reached $84.38 \%$ with a very good category. This was in line with the research conducted by Estu (2014) which stated that the activity of students in learning using the creative problem-solving learning model in the precycle reached the percentage of $42.85 \%$ with the medium criteria. Then, in the first cycle, the percentage increased to $61.90 \%$ with high criteria. In the second cycle, the percentage increased to $85.71 \%$ with very high criteria.

The measurement of the effectiveness of the second creative problem-solving learning model learning model was the student's responses to learning using the learning model. The students' responses consisted of two aspects, namely students' attitudes toward learning through the creative problem-solving learning model and the students' material understanding that being taught. Based on the results obtained, the students' responses showed a very good response to every aspect. The percentage obtained in the first aspect reached $81.29 \%$. Whereas in the second aspect, the percentage reached $83.27 \%$. Overall the responses shown to mathematics learning using the creative problem-solving learning model showed a very good response with a 
percentage of $82.53 \%$. This was in line with research conducted by In'am (2015) which stated that the learning model was stated to be effective if the students' responses were classified as high. In his research showed that the students' responses shown by students belong to the high category with the acquisition of an average of 3.47.

The last measurement of the effectiveness of the creative problem-solving learning model through the completeness of students' learning outcomes. The measurement of completeness of students' learning outcomes was reviewed from the first and second meeting $L K K$ values and the final test conducted at the third meeting. The acquisition of percentage in every aspect could be said to be complete. The percentages of the first and second meeting $L K K$ could be said to be complete. Likewise, the acquisition of percentages in the final test could be said to be complete. This happened because the percentage obtained by the final test was above $70 \%$. Classically, the percentage of students could be said to be completed with a percentage of $71.88 \%$. This was in line with the research conducted by Estu (2014) which stated that the indicators of the success of students' learning outcomes were said to be complete if the percentage of completeness showed $\geq 75 \%$, where the value was obtained from the Minimum Completion Criteria (KKM) that set at the school. In his research, showed that the enhancement of students' learning outcomes could be seen from the percentage in the pre-cycle, cycle I and cycle II. The percentage values obtained were $46 \%, 76 \%$, and $96 \%$. In the second cycle, the percentage obtained was $\geq 75 \%$ so that in this cycle the learning could be said to be complete.

Basically, this research measured the effectiveness of the creative problem-solving learning model in mathematics learning in $8^{\text {th }}$ grade of Junior High School of Taman Siswa Malang. The measurement of the effectiveness of the learning model in this research referred to the assessment of the effectiveness of the learning model proposed by In'am (2014). The assessment of the effectiveness of the learning model was reviewed based on the students' activities, students' responses, and students' learning outcomes. The learning model was stated to be effective if these aspects were fulfilled. The students' activities showed a positive attitude, positive response, and the students' learning outcomes could be said to be complete.

Based on the results of the research, the students' activities showed a positive attitude. This could be seen from the activities of students who showed very good attitudes. The students' responses to the learning model showed a positive response. In addition, classically the students' learning outcomes could be said to be complete. Therefore, the creative problemsolving learning model in mathematics learning at $8^{\text {th }}$ grade of Junior High School of Taman Siswa Malang could be said to be effective

\section{CONCLUSION}

Based on the results of the research and discussion that has been described, the students' activities shown in the implementation of the creative problem-solving learning model belong to the very good category with a percentage of $84.38 \%$. The students' responses to learning using the creative problem-solving learning model are included in the very good category with a percentage of $82.53 \%$. The students' learning outcomes through the creative problem-solving learning model are classically complete with the completeness of $71.88 \%$. Thus, it can be concluded that the implementation of the creative problem-solving learning model is reviewed based on the students' activities, students' responses, and students' learning outcomes in mathematics learning at $8^{\text {th }}$ grade of Junior High School of Taman Siswa Malang that can be said to be effective 


\section{REFERENCES}

Estu, L. (2014). Konsep Matematika Siswa Melalui Creative Problem Solving Siswa KELAS XI-IPA1 SMA NEGERI I IMOGIRI, 2(2), 183-190.

Firmansyah, A. (2014). Peningkatan Kemandirian Belajar dan Hasil Belajar Matematika dengan Strategi Savi (Pada Siswa Kelas VII Semester 2 SMP Negeri 1 Klego Boyolali Tahun Pelajaran 2012/2013). Universitas Muhammadiyah Surakarta.

In'am, A. (2014). Efektivitas Model Pembelajaran Matematika berbasis Metakognitif, 21(1), 24-32.

Prameswari, N., \& Khabibah, S. (2016). Profil Pemecahan Masalah Matematika Siswa SMP Ditinjau Dari Adversity Quotient (AQ), 348-357.

Retna, M., Mubarokah, L., \& Suhartatik. (2013). Proses Berpikir Siswa dalam Menyelesaikan Soal Cerita Ditinjau Berdasarkan Kemampuan Matematika (The Student Thinking Process In Solving Math Story Problem), 1(2), 71-82.

Shodikin, A. (2015). Peningkatan Kemampuan Pemecahan Masalah Siswa melalui Strategi Abduktif-Deduktif pada Pembelajaran Matematika, 6(2), 101-110.

Shoimin, A. (2014). 68 Model Pembelajaran Inovatif dalam Kurikulum 2013. (R. KR, Ed.) (cetakan I). Yogyakarta: Ar Ruzz Media.

Suprijono, A. (2012). Cooperative Learning Teori dan Praktik PAIKEM (Cetakan VI). Yogyakarta: Pustaka Pelajar.

Syazali, M. (2015). Pengaruh Model Pembelejaran Creative Problem Solving Berbantuan Maple II Terhadap Kemampuan Pemecahan Masalah Mtematis. Junal Pendidikan Matematika, 6(1), 9198.

Yudharina, P. (2015). Meningkatkan Kemampuan Menyelesaikan Soal Cerita Matematika Siswa Kelas V SD Negeri Mejing 2 Melalui Model Pembelajaran Creative Problem Solving Tahun Ajaran 2014/2015. Universitas Negeri Yogyakarta. 